or 3-O-methylglucose was observed. We therefore found no evidence of a capacity of Ascaris intestine to translocate sugars across the mucosal cells against a concentration gradient. With maltose present in the lumen no disaccharide was detected in chromatograms of the coelomic fluid, and after absorption for $10 \mathrm{~min}, 41.2$ per cent of the total reducing substances in the lumen were accounted for as glucose. No maltose appeared in the intestinal lumen when the sugar was added to the coelomic fluid only. Absorption of glucose from the intestinal lumen was reduced when the sodium ions in the luminal fluid were replaced by $\mathbf{K}$ ions or by tris buffer. Glucose absorption was also partially inhibited by phloridzin.

Table 1. MOVEMENT OF SUGAR ACROSS INTESTINE OF Ascaris lumbricoides

SCRVIVING in vitro

Sugars in luminal fluid
only
Glucose $\left(\mathrm{Na}^{+}\right)$
Glucose (K+)
Glucose (tris)
Glucose (phloridzin)
Fructose
Galactose
Maltose (as hexose)
3-0-methylglucose
D-xylose
Sugars in luminal and
coelomic fluids
Glucose
3-O-methylglucose
Fructose
Sugars in coelomic fluid
only
Glucose
Fructose
Galactose
1-xylose
Maltose (as hexose)
3-0.methylglucose

10
10
10
10
10
10
10
60
60

$\begin{array}{rc}n & \begin{array}{c}\text { Absorption } \\ \text { from lumen }\end{array} \\ 7 & 33 \cdot 1 \pm 2 \cdot 7 \\ 6 & 10 \cdot 8 \pm 6 \cdot 1 \\ 6 & 17 \cdot 8 \pm 3 \cdot 8 \\ 10 & 23 \cdot 2 \pm 4 \cdot 3 \\ 8 & 26 \cdot 4 \pm 3 \cdot 6 \\ 7 & 2 \cdot 9 \pm 2 \cdot 0 \\ 6 & 14 \cdot 6 \pm 3 \cdot 8 \\ 9 & 12 \cdot 4 \pm 3 \cdot 2 \\ 6 & 6 \cdot 3 \pm 1 \cdot 5 \\ & \text { Absorption } \\ n & \text { from lumen } \\ 6 & 32 \cdot 2 \pm 6 \cdot 2 \\ 6 & 3 \cdot 6 \pm 1 \cdot 2 \\ 7 & 11 \cdot 2 \pm 1 \cdot 4\end{array}$

Appearance in coelomic fluid $19 \cdot 6 \pm 1 \cdot 0$ $5 \cdot 1 \pm 1 \cdot 4$
$10 \cdot 6+2 \cdot 8$ $10 \cdot 6 \pm 2 \cdot 8$ $15 \cdot 1 \pm 1 \cdot 7$ $7 \cdot 2+4 \cdot 3$ $0 \cdot 0$ $19 \cdot 5+5 \cdot 2$ $9 \cdot 2 \pm 1 \cdot 0$ $32 \cdot 2 \pm 6 \cdot 2 \quad 391 \cdot 4 \pm 77 \cdot 3$ $\begin{array}{rrrr}60 & 6 & 3 \cdot 6 \pm 1 \cdot 2 & 23 \cdot 5 \pm 6 \cdot 6 \\ 10 & 7 & 11 \cdot 2 \pm 1 \cdot 4 & 92 \cdot 5 \pm 6 \cdot 2\end{array}$

Absorption from coelomic fluid $511 \cdot 7 \pm 2 \cdot 7$ $218 \cdot 5 \pm 6 \cdot 0$ $65 \cdot 6 \pm 5 \cdot 8$ $129 \cdot 3 \pm 15 \cdot 6$

$\begin{array}{lcccr}\text { Maltose (as hexose) } & 30 & 6 & & 10 \cdot 2 \pm 6 \cdot 0 \\ 3-0 \cdot m e t h y l g l u c o s e & 60 & 7 & 6 & 6 \cdot 6 \pm 3 \cdot 7\end{array}$

Units are $\mathrm{mM}$ wet wt ${ }^{1}$ and are means $\pm \mathbf{S}$. E. of mean; $t$, time of observation $(\mathrm{min})$; $n$, number of sacs. The initial concentration of glucose was
$16.6 \mathrm{mM}$; D-xylose was $20.0 \mathrm{mM}$; maltose was $5.5 \mathrm{mM}$; $3-0$-methylglucose was $15.5 \mathrm{mM}$. The concentration of phloridzin was $5 \times 10^{-4} \mathrm{M}$; $\mathrm{Na}$ and glucose were $154 \mathrm{mM}$, except for glucose $\left(\mathrm{K}^{+}\right)$and glucose $($tris $)$when 154 $\mathrm{mM}$ of $\mathrm{Na}$ in the luminal fluid were replaced either by $\mathrm{K}^{+}$or by tris.

When uniformly labelled ${ }^{14} \mathrm{C}$-glucose was 'used approximately half the radioactivity incorporated into the cell during glucose absorption was in the form of glycogen. During glucose absorption in aerobic or anaerobic conditions several unidentified glucose metabolites appeared in the luminal and coelomic fluids. The intestine seems to metabolize glucose and fructose rapidly, for both of these sugars disappear rapidly from the coelomic fluid.

In further experiments, undertaken to examine the kinetics of glucose absorption, a constant concentration of glucose was maintained in the intestinal lumen by continuous infusion. By this procedure we found that the mechanism by which glucose is transported from the lumen into the cells can be saturated and that the relationship between glucose uptake and glucose concentration in the lumen seems to be of the Michaelis-Menten type. The parameters of this relationship were estimated as $V_{\max }=9 \cdot 2 \mathrm{nM} \mathrm{mg}$ wet weight-1 $\min ^{-1}$ and $K_{m}=9 \cdot 1 \mathrm{mM}$. The $V_{\max }$ represents the limiting rate of transport of glucose into the cells with high concentrations of sugar in the lumen; the $K_{m}$ represents the Iuminal concentration of glucose necessary to yield half the maximum rate of glucose absorption.

As in mammalian intestine, the rate of entry of glucose into the Ascaris intestinal cells seems to be determined partially, but not entirely, by a process which is sensitive to phloridzin and dependent on the presence of sodium ions in the lumen. There is also evidence for the existence of maltase in the brush border region. We conclude that specific processes for the transport, at least of glucose, exist on the luminal face of the intestinal cells of Ascaris lumbricoides, but these cells, unlike those of mammalian intestine, do not seom to possess the capacity for moving hexoses across the epithelial layer against a concentration gradient. In Ascaris intestine, glucose and fructose are absorbed much more rapidly than galactose and 3-O- methylglucose. This is in contrast to what is found for mammalian small intestine ${ }^{8}$ and may be related to a high rate of glucose and fructose metabolism by the intestinal mucosal cells of the nematode.
P. Sanhueza
R. Palma
E. OBERHAUStr
H. ORREGo
D. S. Parsons
A. Salinas

Universidad de Chile,

Centro Gastroenterologica,

Hospital Clinico "Jose-Joaquin Aguirre",

Santiago de Chile, and

Department of Biochemistry,

University of Oxford.

Received July 16, 1968.

${ }^{1}$ Lee, D. L., Physiology of Nematodes (Oliver and Boyd, Edinburgh, 1965).

${ }^{2}$ Umbreit, W. W., Burris, R. H., and Stauffer, J. H., Manometric Techniques in Tissue Metabolism, fourth ed. (Burgess Publishing Company, Minneapolis, 1964).

${ }^{3}$ Dahlqvist, A., Anal. Biochem., 7, 18 (1964).

4 Somogyi, M., J. Biol. Chem., 195, 9 (1952).

${ }^{5}$ Roe, J. H., and Rice, E. W., J. Biol. Chem., 178, 507 (1948).

${ }^{6}$ Roe, J. H., J. Biol. Chem., 10\%, 15 (1934).

${ }^{7}$ Montgomery, R., Arch. Biochem. Biophys., 6', 378 (1957).

${ }^{8}$ Wilson, T. H., Intestinal Absorption (W. B. Saunders, Philadelphia, 1962).

\section{Gamete Shedding Behaviour of the Feather-star Lamprometra klunzingeri in its Natural Habitat}

INFORMATION on the reproductive behaviour of featherstars, especially in their natural habitats, is very scarce. Among the widely cited investigations are those on the development and larval forms of Echinodermata ${ }^{1}$ and the publications that describe gamete production in the crinoid Comanthus japonicus ${ }^{2}$ and its correlation with the declination of the Moon ${ }^{3}$.

As far as I know, this is the first report of the gamete shedding behaviour of a feather-star in its natural habitat (Eilat, Red Sea).

Lamprometra klunzingeri is a shallow water species living among corals of the fringing reefs, forming populations that may reach twenty to sixty individuals on one square metre. It is active at night.

On May 22, 1968, at $1745 \mathrm{~h}$, individuals were observed climbing out of their daytime hiding places on an isolated coral block at a depth of $2 \mathrm{~m}$. At $1800 \mathrm{~h}$ twelve were found attached by their cirri along a deep notch in this block with fully extended arms and swollen genital pinnules. At approximately the same time, one of these individuals started violent undulations of its arms, and after several seconds the remaining individuals were whipping their arms vigorously. Simultaneously, a dense greenish-coloured cloud of gametes arose around them, partly covering them. Arm-whipping continued for $25 \mathrm{~s}$ and then stopped abruptly. Part of the gamete-cloud moved down into the crevice, while the rest was washed away by the water current.

Laboratory observations revealed that the individual which began the gamete shedding was a male and that in this group there were females and males. It may be worthwhile mentioning that near to the observed group of spawning $L$. klunzingeri there were individuals of another feather-star, Capillaster multiradiatus, but they did not react to the sexual behaviour of their neighbours.

Department of Zoology,

Lev Fishelson

University of Tel-Aviv.

Received June 6; revised July 15, 1968.

${ }^{1}$ Mortensen, Th., Kong. danske Vidensk. Selsk. Skrift., Nat. Mat. Afd., 9, raekke, 'ry (1), 1 (1937).

${ }^{2}$ Dan, K., and Dan, J. C., Jap. J. Zool., 9, 555 (1941)

${ }^{3}$ Dan, K., and Kubota, H., Kimbryologia, 5, 21 (1960). 